\title{
ANALISIS MORFOLOGI FISIK KALDERA MASURAI JAMBI MENGGUNAKAN CITRA SATELIT RESOLUSI TINGGI
}

\section{ANALYSIS OF THE PHYSICAL MORPHOLOGY OF THE}

\section{JAMBI MASURAI CALDERA USING HIGH}

\section{RESOLUTION SATELLITE IMAGE}

\author{
Yulia Morsa Said ${ }^{1}$, Hari Wiki Utama ${ }^{2^{*}}$ \\ 1,2Teknik Geologi, FST, U niversitas Jambi
}

Received: 2021, September $25^{\text {th }}$ Accepted: 2021, October $19^{\text {th }}$

\section{Keywords: \\ Landscapes; \\ M asurai Caldera; \\ Physical morphology; \\ Satellite imagery.}

\section{Corespondent Email:}

h.wikiutama@unja.ac.id

\section{H ow to cite this article:}

Said, Y.M .\& U tama, H.W . (2021). Analisis M orfologi Fisik Kaldera M asurai Jambi M enggunakan Citra Satelit Resolusi Tinggi. Jurnal Geofisika Eksplorasi, 07(03), 178-190.

\begin{abstract}
Abstrak. Kaldera Masurai Jambi merupakan kaldera terakhir yang ditemukan di Pulau Sumatera. Keberadaan kaldera yang berumur Plistosen Akhir ini sebagai bagian dari pembentukan kaldera di sepanjang Perbukitan Barisan. Informasi geologi terkait kaldera ini sangat sedikit, sehingga diperlukan penelitian geologi detail yang diawali dengan analisis morfologi fisik kaldera. Tujuan penelitian ini untuk memahami morfologi fisik Kaldera Masurai dengan menggunakan analisis citra resolusi tinggi yang merupakan upaya untuk mengetahui proses pembentukan morfologi kaldera dan posisinya secara geologi terhadap keberadaan kaldera lainnya. Untuk mendukung penelitian ini, menggunakan metode pengamatan dan analisis model elevasi digital ASTERGDEM, Citra Satelit Ikonos dan Citra Quickbird, observasi bentang alam, dan pemetaan geologi. Morfologi fisik Kaldera Masurai terdiri dari Morfologi puncak kaldera dengan bentang alam dan manifestasi seperti cincin kaldera, kawah gunung api dari Kawah Kumbang, Kawah Mabuk, Kawah Merah Tanjung Brugo, dan fosil Kawah Dikit, dan Gunung M asurai M uda. M orfologi lereng kaldera proksimal-medial dengan bentang alam dan manifestasi meliputi kerucut Gunung Dikit yang merupakan bagian dari kerucut parasiter Gunung Masurai Tua dan kerucut Gunung Lupi yang merupakan bagian dari kerucut parasiter Gunung M asurai Muda. M orfologi kaki atau distal kaldera dengan bentang alam dan manifestasi seperti Danau Pauh dan Danau Kecil sebagai bagian dari jejak erupsi samping atau kerucut sinder Gunung M asurai M uda. Karakteristik bentang alam dan manifestasi kaldera merupakan hasil proses geologi yang membentuk morfologi Kaldera M asurai.
\end{abstract}

\begin{abstract}
Masurai Caldera, Jambi is the last caldera found in Sumatera. The existence of the caldera of the Late Pleistocene is part of caldera formation along the Barisan Range. There is measly the geological information regarding this caldera, then the detailed geological research is needed, which begins with
\end{abstract}


(c) 2021 JGE (Jurnal Geofisika Eksplorasi). This article is an openaccess article distributed under the terms and conditions of the Creative Commons Attribution (CC BY NC) physical analysis morphology of the caldera. The study aims to comprehend the physical morphology of Masurai Caldera using analysis of high-resolution satellite images; they are an attempt to find out the formation process of caldera morphology and spatial geological relationship the presence of another caldera. To support this research, use methods including observation and analysis AST ERGDEM digital elevation model, Ikonos Image, Quickbird Image, landscape observation, and geological mapping. The physical morphology of Masurai Caldera as landscape and manifestations consist of central caldera peak, proximal-medial caldera slope, and distal caldera. The central caldera peak morphology is composed of caldera ring, volcanic crater lake such as Kumbang Crater, Mabuk Crater, M erah Tanjung Brugo Crater, and fossil of Dikit Crater, and Young Masurai Volcanic Cone. Proximal-medial caldera slope including Dikit Volcanic Cone the part of the parasitic cone of Old Masurai Volcanic and Lupi Volcanic Cone the part of the parasitic cone of Young Masurai Volcanic. Distal caldera morphology consists of Pauh Lakeand Kecil Lake, the part of flank eruption fossil of sinder cone of Young $M$ asurai Volcanic. The characteristics of the caldera landscape and manifestations are the product of the geological process forming the M asurai Caldera morphology.

\section{PENDAHULUAN}

Sumatera merupakan representasi dari amalgamasi mikrokontinen yang terjadi selama Paleozoikum Akhir - Mesozoikum Akhir Metcalfe (R. Hall \& Spakman, 2015; M etcalfe, 2013, 2017). Dinamika proses geologi yang terjadi dalam waktu tersebut hingga saat ini memberikan perubahan pada morfologi ataupun bentang alam, terutama di sepanjang Zona Perbukitan Barisan yang berasosiasi dengan Sesar Sumatera dan rangkaian gunung api Kuarter (Hutchison, 2014; Utama dkk., 2021). Tatanan geologi yang kompleks di sepanjang zona tersebut menjadi fokus penelitian oleh peneliti kebumian dalam satu dekade terakhir, terutama berkaitan dengan sistem gunung api dan kaldera. Sumatera dengan 7 kaldera gunung api meliputi Kaldera Toba Sumatera Utara, Kaldera Maninjau Sumatera Barat, Kaldera Kerinci dan Kaldera Gunung Tujuh Jambi, Kaldera Ranau Sumatera Selatan dan Lampung, Kaldera Suoh Lampung, dan Kaldera Krakatau Selat Sunda merupakan bagian dari morfologi yang terbentuk sebagai akibat dari erupsi gunung api (KESDM, 2015). Kaldera Masurai Jambi merupakan penemuan kaldera terbaru di Sumatera yang tidak termasuk ke dalam data gunung api aktif di Indonesia (KESDM , 2021). Oleh karenanya, memahami morfologi fisik Kaldera Masurai melalui analisis serta interpretasi bentang alam dan manifestasi merupakan hal signifikan untuk memberikan informasi mengenai Kaldera M asurai.

Kaldera Masurai secara administratif termasuk ke dalam Kabupaten Merangin Provinsi Jambi. Kaldera ini juga memiliki rangkaian kompleks gunung api di bagian baratlaut, meliputi Gunung Api Hulunilo dan Gunung Api Sumbing yang dipisahkan oleh Sesar Masurai berarah relatif timurlaut baratdaya (Gambar 1). Saat ini Kaldera Masurai berbentuk setengah lingkaran menyerupai huruf " $c$ " terbalik pada bagian cincin kaldera timur dengan lereng yang curam sedangkan pada bagian barat dengan lereng yang relatif lebih landai. M orfologi fisik kaldera ini sebagai suatu indikasi geodinamika erupsi gunung api sehingga membentuk morfologi yang khas pada Kaldera Masurai. Pembentukan kaldera pada suatu gunung api sangat dipengaruhi oleh mekanisme erupsi 
gunung api (H all, 2012, 2013, 2014; Hernando dkk., 2016, 2019; Valentine \& Cole, 2021).

Kaldera Masurai tidak tercatat sebagai gunung api aktif di Indonesia yang kontradiktif dengan Gunung Api Sumbing yang merupakan tipe gunung api B (KESDM, 2021). Hal ini menunjukkan keterbatasan data terkait keberadaan Kaldera M asurai. Penelitian yang intensif dari tatanan geologi kaldera menjadi suatu kunci untuk memahami secara utuh dari keberadaan kaldera ini. Dengan cara menganalisis morfologi fisik kaldera serta kaitannya dengan bentang alam dan manifestasi geologi. Penelitian pertama yang dilakukan oleh Badan Geologi melalui Pusat Survei Geologi tahun 2015 diketahui bahwa erupsi pembentukan kaldera berumur 33000 tahun yang lalu, yaitu sekitar Plistosen A khir. Penelitian ini menjadi jendela utama untuk mengetahui lebih lanjut dari keberadaan penemuan terakhir kaldera di Sumatera.

Bentang alam Kaldera M asurai merupakan manifestasi geologi yang terjadi selama proses erupsi yang melibatkan dinamika geologi, sehingga membentuk suatu morfologi fisik kaldera saat ini. Bentukan morfologi puncak, lereng, hingga kaki kaldera memiliki ciri khas tersendiri, sebagai suatu fasies dari sistem gunung api (East dkk., 2020; Grosse \& Kervyn, 2018; Zahirovic dkk., 2014). Keberadaan kaldera ini berada di bagian barat dari jalur sesar aktif Sumatera dari Segmen Dikit (N atawidjaja, 2018; U tama dkk., 2021).

Tujuan dari penelitian ini untuk memahami dari morfologi fisik Kaldera Masurai yang berhubungan dengan bentang alam dan manifestasi berdasarkan peta geologi fasies gunung api. Informasi mengenai kaldera ini sangat terbatas dan baru hanya sebatas survei dari Badan Geologi tahun 2015. Kaldera ini juga merupakan bagian dari Kawasan Merangin Jambi Geopark. Oleh karenanya merupakan suatu hal yang signifikan untuk memberikan informasi dari Kaldera Masurai.

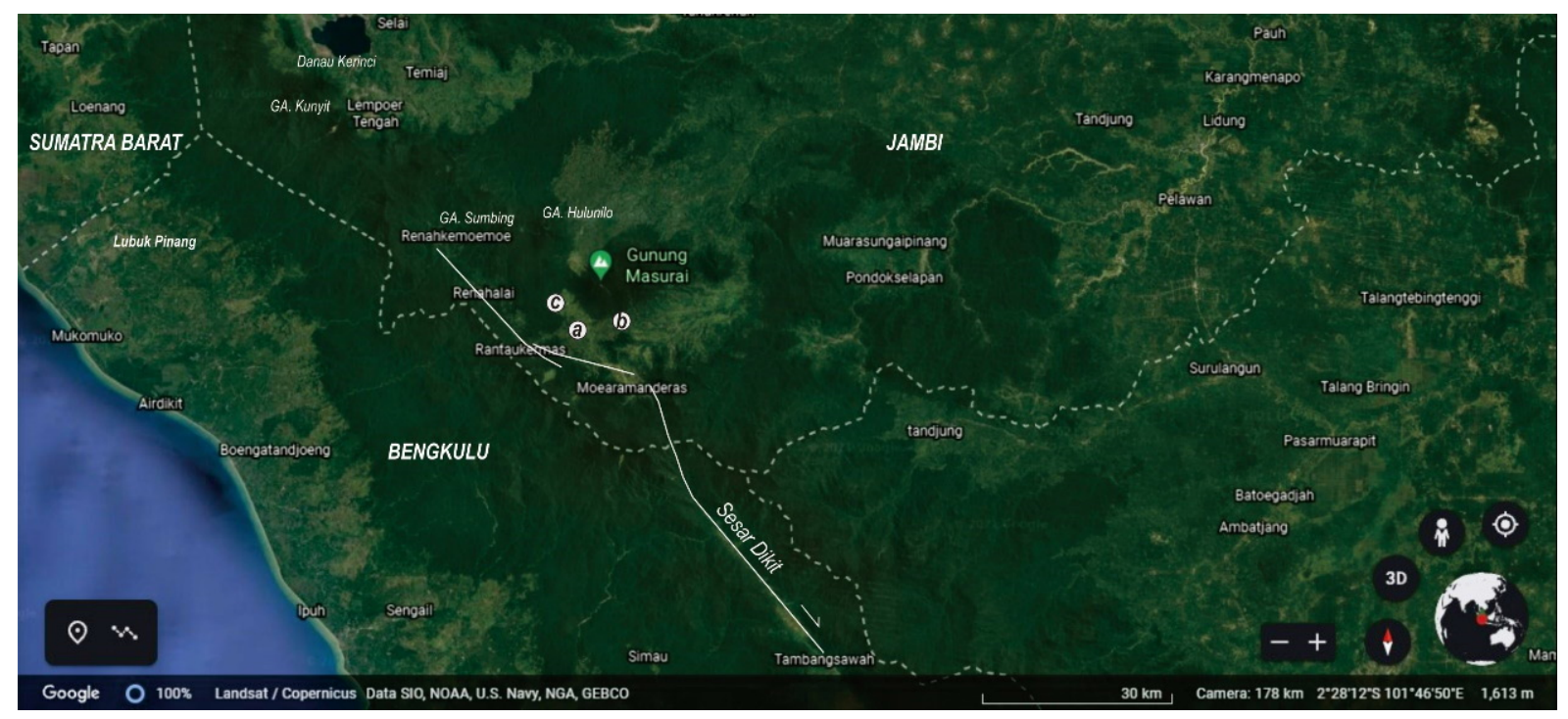

Gambar 1. Peta situasi daerah penelitian yang termasuk ke dalam administrasi Kecamatan Jangkat, Kabupaten M erangin, Provinsi Jambi. Kaldera M asurai berada di bagian timur dari Segmen Dikit (Garis putih tegas) yang merupakan sesar aktif Sumatera.

\section{TINJAUAN PUSTAKA}

Pulau Sumatera memiliki fisiografi yang mencirikan topografi, fisik, struktur, dan sejarah geologi yang kompleks (Utama dkk.,
2021; Van Bemmelen, 1949). Fisiografi tersebut dapat dibagi menjadi enam zona fisiografi secara umum, meliputi Zona Paparan Sunda, Zona Perbukitan Rendah dan Dataran Bergelombang, Zona Perbukitan Tigapuluh, 
Zona Perbukitan Barisan dengan sub-zona Gunung Api Kuarter, sub-zona Pegunungan, dan sub-Zona Cekungan Antar Busur; Zona Sesar Sumatera, dan Zona Busur Terluar. Zona fisiografi ini memberikan gambaran dari dinamika morfologi di Pulau Sumatera. Kaldera M asurai merupakan bagian dari Zona Perbukitan Barisan dari sub-zona Gunung Api Kuarter.

Pembentukan kaldera umumnya disebabkan oleh erupsi dan runtuhan puncak gunung api yang diakibatkan oleh ruang kosong pada kantong magma (Geshi dkk., 2014, 2020; G ottsmann \& M arti, 2008). Dalam proses pembentukan kaldera, evolusi magma dan injeksi magma mafik akan berperan penting dari terjadinya proses diferensiasi magma pada suatu gunung api (Favallim dkk., 2005; Gregg dkk., 2015; Rachmat dkk., 2016). Morfologi kaldera sebagai hasil dari proses erupsi dan runtuhan puncak gunung api diakibatkan oleh proses diferensiasi magma yang terjadi selama erupsi diiringin dengan pembentukan struktur sebagai media dari zona permeabilitas oleh pengaruh suhu dan tekanan (Grosse \& Kervyn, 2018; Karlstrom dkk., 2015; $\checkmark$ alentine \& Sweeney, 2018).

Kaldera gunung api bisa terbentung pada morfologi gunung api strato ataupun gunung api perisai (Hernando dkk., 2019; Sweeney dkk., 2018; Sweeney \& Valentine, 2017; Thouret, 1999). Morfologi gunung api strato memiliki ciri fisik dengan lereng relatif miringterjal, disusun oleh lava andesitik-dasitik dan batuan piroklastik, memiliki pusat erupsi, terkadang memiliki erupsi samping, dipengaruhi oleh ekstensi lemah atau kompresi (Gudmundsson, 2012; Valentine dkk., 2019; Yasuda \& Suzuki-Kamata, 2018). Pada morfologi gunung api perisai umumnya memiliki lereng landai, khas litologi lava basaltik-andesit basaltik yang diakibatkan oleh visikositas magma rendah, pusat erupsi utama terkadang sulit ditemukan, tidak adanya erupsi samping, umumnya dipengaruhi oleh rezim ekstensi kuat (Geshi dkk., 2020; Grosse \& Kervyn, 2018).

\section{METODE PENELITIAN}

Penelitian ini menggunakan metode analisis morfologi fisik kaldera menggunakan citra resolusi tinggi melalui pengamatan model elevasi digital ASTER-GDEM, pengamatan dan interpretasi Citra Satelit Google Earth dari Citra Ikonos dan Citra Quickbird, dan observasi morfologi atau bentang alam di lapangan. Ketiga metode analisis tersebut akan dipadukan dengan analisis pada pemetaan geologi kompleks kaldera, sehingga dapat mengetahui morfologi fisik kaldera dan manifestasi yang berkaitan dengan bentang alam dan manifestasi geologi.

\subsection{Pengamatan dan Interpretasi Model Elevasi Digital}

Model elevasi digital didapatkan dari Citra ASTER-GDEM dengan resolusi $30 \mathrm{~m}$ (Hayati \& Taufik, 2011; Suwargana, 2013; Utama, 2020). Resolusi citra ini digunakan untuk mengetahui morfologi secara umum, sehingga akan didapatkan karakteristik luasan moforlogi dari kaldera, seperti bentuk cincin kaldera dengan orientasinya, gawir sesar, zona amblesan, sehingga dapat mengetahui orientasi kelurusan pada kaldera. Citra digital ini bisa digunakan pada tahapan awal penelitian ataupun beriringan dengan citral digital yang memiliki resolusi lebih tinggi. Ketersediaan citra digital ini dapat diunduh melalui Asterweb JPL California Institute of Technology.

\subsection{Pengamatan dan Interpretasi Citra Ikonos dan Citra Quickbird}

Citra digital ini diterbitkan oleh Digital Globe melalui aplikasi Google Earth. Citra ini merupakan bagian spesifik dari Citra Landsat yang bertujuan untuk observasi topografi. Citra Ikonos yang merupakan citra satelit dengan resolusi $4 \mathrm{~m}$ yang mampu merekam 
data multispectral 4 kanal sedangkan Citra Quickbird memiliki resolusi spasial $0.68 \mathrm{~m}$ (Adler \& Pratama, 2018; Rudianto, 2010). Sehingga citra ini sangat mendukung untuk mengetahui morfologi suatu gunung api ataupun kaldera dengan konsep geologi penginderaan jauh. Pengamatan dan analisis citra digital ini nantinya, akan didapatkan secara terperinci dari bentang alam dan manifestasi geologi di morfologi fisik kaldera.

\subsection{Observasi Bentang Alam}

Observasi bentang alam di lapangan yang didukung dengan analisis morfologi sebagai salah satu upaya untuk melihat secara langsung fenomena geologi yang menyertai dari dinamika morfologi fisik kaldera (Favallim dkk., 2005; Grosse \& Kervyn, 2018). Observasi bentang alam ini juga mengamati singkapan batuan di lapangan, sebagai bagian dari korelasi geologi dalam menentukan tipe gunung api strato atau perisai.

Analisis morfologi dari hasil observasi bentang alam akan didapatkan morfologi kompleks dari kaldera dan manifestasi geologi yang tersingkap di sepanjang area observasi. Analisis ini meliputi aspek morfografi dan morfometri dan mempertimbangkan aspek morfogenesis (Utama, 2020).

\subsection{Pemetaan Geologi}

Peta geologi dihasilkan dari observasi Citra Model Elevasi Digital, Citra Ikonos, Citra Quickbird, dan observasi singkapan di lapangan. Integrasi dari keempat data tersebut, didapatkan satuan stratigrafi gunung api ataupun kaldera. Pengamatan dengan menggunakan citra digital dengan menganalisis pola kontur, pola pengaliran sungai, morfologi, maka akan didapatkan batas-batas satuan stratigrafi yang mempertimbangkan fasies gunung api atau kaldera. Observasi singkapan di lapangan untuk melihat penyebaran dan susunan stratigrafi dari kaldera.

Integrasi dari pengamatan dan interpretasi model elevasi digital, pengamatan dan analisis Citra Ikonos dan Citra Quickbird, observasi bentang alam, yang dipadukan dengan analisis dalam peta geologi Kaldera M asurai, sehingga dapat mengetahui secara terperinci dari morfologi fisik kaldera yang hubungannya terhadap bentang alam dan manifestasi.

\section{HASIL DAN PEMBAHASAN}

Perpaduan dari citra digital dan observasi geologi di lapangan melalui pengamatan bentang alam dan singkapan batuan, morfologi fisik Kaldera Masurai yang berhubungan dengan bentang alam dan manifestasi geologi, meliputi morfologi puncak utama "sentral" kaldera dengan kawah gunung api, jejak kawah gunung api; lereng kaldera proksimal-medial dengan bagian kerucut gunung api; dan kaki kaldera distal. Analsis larakteristik morfologi dari Kaldera M asurai dapat dibedakan menjadi dua bagian morfologi, yaitu morfologi Gunung Masurai Tua bagian timur dan morfologi Gunung Masurai Muda bagian barat yang dibatasi oleh Sesar M asurai M uda (Gambar 2). 


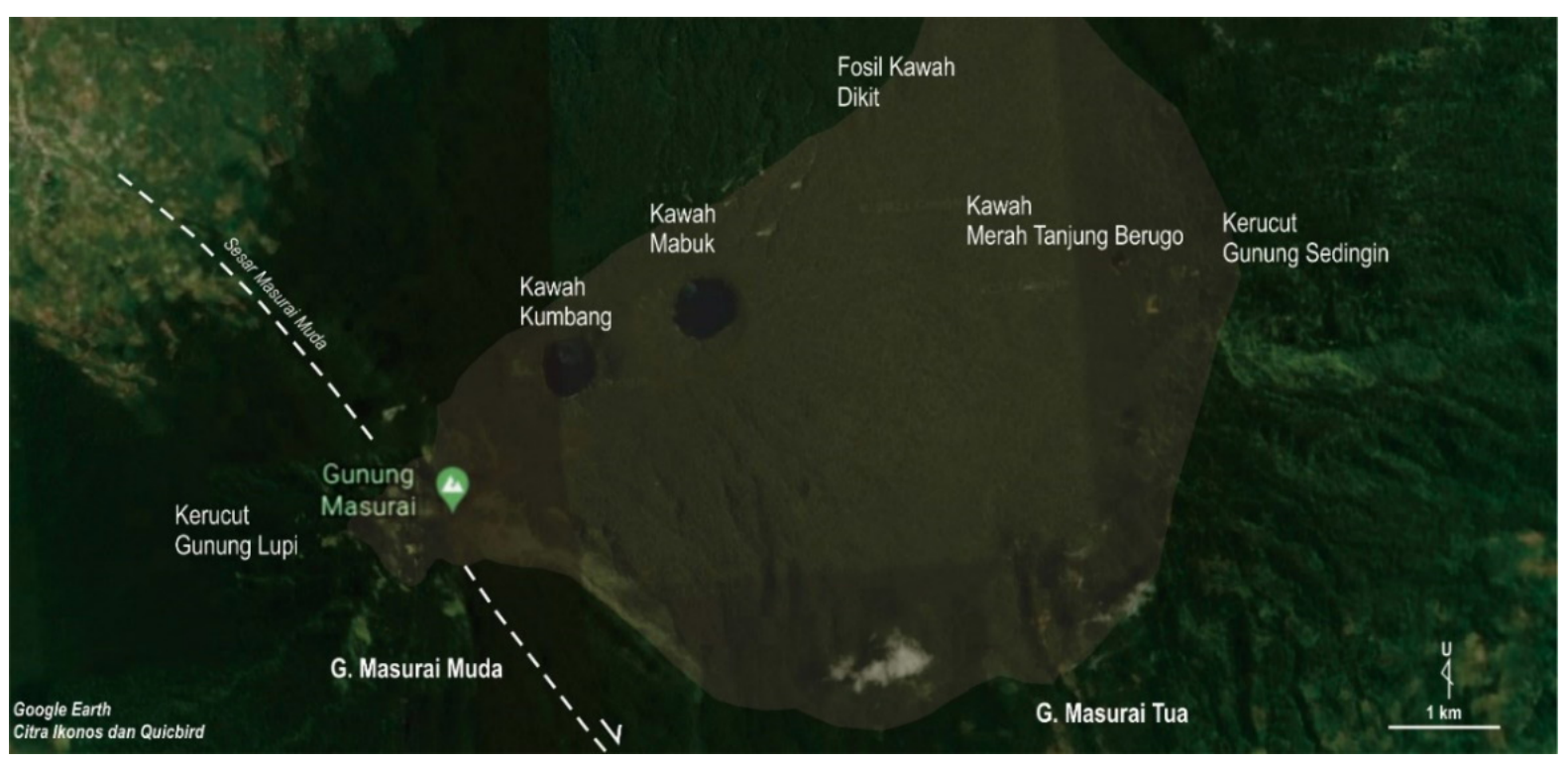

Gambar 2. Morfologi struktur puncak Kaldera Masurai (merah muda transparan). Kompleks kaldera ini meliputi Gunung M asurai Tua dan Gunung M asurai M uda yang dibatasi oleh Sesar M asurai M uda.

\subsection{M orfologi Puncak Kaldera Masurai}

Pada morfologi ini berasosiasi dengan sesar normal. Kaldera ini memiliki diameter sekitar 7,4 km berarah timurlaut - baratdaya dan 5,4 $\mathrm{km}$ berarah baratlaut - tenggara. Cincin kaldera bagian timur memiliki dinding yang relatif terjal/curam sekitar $60^{\circ}-75^{\circ}$, dengan ketinggian mencapai $2.275 \mathrm{mdpl}$, beda tinggi 500 m-1000 m lebih yang merupakan topografi curam-sangat curam, pola pengaliran radial sentrifugal. Pada cincin kaldera bagian barat memiliki dinding yang relatif lebih landai daripada bagian timur, yaitu sekitar $25^{\circ}-40^{\circ}$, dengan ketinggian $1880 \mathrm{mdpl}$, topografi agak curam - agak landai, pola pengaliran radial sentrifugal. Pada bagian baratdaya cincin kaldera terdapat kerucut Gunung Masurai dengan elevasi mencapai 2910 mdpl yang merupakan kerucut gunung baru pasca erupsi.

Pada morfologi puncak kaldera yang merupakan zona depresi, dengan pola pengal iran radial sentripetal, kelerengan lereng berkisar $50^{\circ}-75^{\circ}$ pada bagian timur dan $25^{\circ}$ $40^{\circ}$ pada bagian barat. Pada morfologi ini juga terdapat danau kawah gunung api, meliputi Kawah Kumbang, Kawah Mabuk, dan Kawah M erah Tanjung Berugo, dan jejak Kawah Dikit ataupun Depresi Dikit. Kawah Kumbang memiliki diameter $0.51 \times 0.48 \mathrm{~km}$, dengan kemiringan lereng agak landai - agak curam, kawah ini berada di bagian timurlaut kerucut Gunung Masurai. Kawah Mabuk berada di bagian timur hingga tenggara dari Kawah Kumbang, diameter $0.54 \times 0.52 \mathrm{~km}$, dengan lereng agak landai - agak curam. Kawah Kumbang dan Kawah Mabuk memiliki kelerengan yang relatif lebih landai di bagian baratdaya dan lebih terjal di bagian timurlaut.

Kawah Merah Tanjung Berugo memiliki diameter $0.19 \times 0.16 \mathrm{~km}$ dengan morfologi kawah yang tidak teratur jika dibandingkan dengan morfologi Kawah Kumbang dan Kawah Mabuk, kawah ini berada di bagian timur kaldera yang berdekatan dengan kerucut Gunung Sedingin di bagian timurnya. Sementara itu, Depresi Dikit ataupun fosil Kawah Dikit, diidentifikasi berdasarkan morfologi yang cekung ataupun depresi, berada di timurlaut kaldera, pada sisi utara hingga timurlaut fosil kawah ini mengindikasikan adanya zona longsoran atau debris, penamaan kawah ini berdasarkan kedekatan toponimi di sekitar kaldera. 


\subsection{M orfologi Lereng Proksimal-Medial}

Pada morfologi lereng puncak proksimal memiliki kelerengan agak curam - curam dengan kelerengan $30^{\circ}-50^{\circ}$, pola pengaliran radial sentrifugal. Pada bagian proksimal juga dicirikan dengan adanya kerucut Gunung Sedingin di bagian timur kerucut Gunung Dikit di bagian utara-timurlaut, dan kerucut Gunung Lupi di bagian barat hingga baratdaya.

Kerucut Gunung Sedingin dengan elevasi $2220 \mathrm{mdpl}$ dan berasosiasi dengan gawir sesar yang berarah timur-timurlaut, gawir ini memberikan ruang pembentukan morfologi lembah yang agak curam - curam dengan kelerengan $50^{\circ}-70^{\circ}$, kerucut gunung ini merupakan kerucut parasitik dari Kompleks Kaldera Masurai. Kerucut Gunung Dikit memiliki elevasi 2130 mdpl, keberadaannya berdekatan dengan fosil Kawah Dikit, kerucut ini memiliki kelerengan agak curam. Kerucut Gunung Lupi memiliki ketinggian mencapai 2719 mdpl, merupakan penamaan kerucut baru dipublikasi dalam artikel ini, kerucut ini diidentifikasi berdasarkan pengamatan dan analisis citra digital yang berada di bagian barat dari Kerucut Gunung M asurai. Pada morfologi lereng proksimal-medial sangat umum berasosiasi dengan sistem sesar ataupun gawir sesar yang berarah timurlaut - baratdaya, tenggara - baratlaut, dan relatif barat - timur. Secara umum morfologi ini memiliki elevasi 2220-1606 mdpl (Gambar 3).

\subsection{Morfologi Kaki Distal Kaldera}

Morfologi ini memiliki 1606-1470 mdpl, pola pengaliran radial sentrifugal, kelerengan $10^{\circ}$ - $20^{\circ}$ landai - agak landai, pada morfologi dibatasi oleh Sesar M asurai terhadap morfologi dari Gunung Hulunilo yang berada di bagian baratlaut kaldera, pada bagian barat hingga selatan dibatasi oleh produk gunung api Tersier dan Sesar Dikit. Bagian utara hingga tenggara menutupi produk batuan metamorf pra-Tersier, dan di bagian timur berasosiasi keberadaannya dengan Gunung Tungkat yang merupakan Gunung Sinder (Gambar 4).

\subsection{Bentang Alam dan Manifestasi Kaldera Gunung Api}

Bentang alam dan manifestasi kaldera gunung api meliputi kawah, kerucut gunung api, di bagian morfologi puncak kaldera, dan juga beberapa danau gunung api di bagian morfologi proksimal-medial berupa Telaga Biru dan di bagian morfologi kaki distal kaldera berupa Danau Pauh dan Danau Kecil merupakan bagian dari manifestasi geologi dari proses pembentukan morfologi Kaldera M asurai (Gambar 5).

Pembentukan morfologi kaldera diyakini sebagai hasil dari: a) Erupsi besar Gunung Masurai Tua selama Plistosen Akhir, berdasarkan pentakrihan umur batuan produk Masurai oleh Badan Geologi Tahun 2015. b) Erupsi besar yang diiringi dengan pembentukan zona runtuhan berupa sesar turun. c) Erupsi ini menghancurkan morfologi puncak hingga lereng proksimal Gunung Masurai Tua yang selaras dengan ruang kosong dari kantong magma akibat erupsi besar tersebut. Erupsi ini menyebabkan hilangnya morfologi puncak dan sebagian lereng proksimal. d) Injeksi magma mafik atau basa diiringi dengan diferensiasi magma, sehingga menyebabkan aktivitas vulkanisme yang baru yang membentuk kerucut Gunung Masurai saat ini yang tumbuh di morfologi puncak - lereng proksimal kaldera saat ini (Gambar 6). 


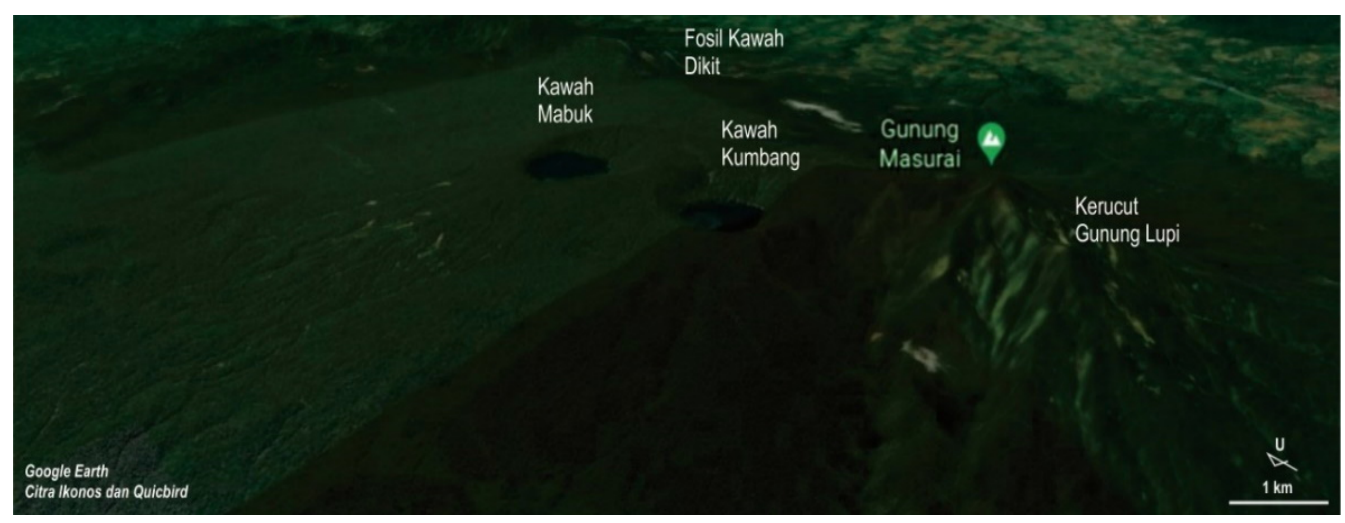

Gambar 3. M orfologi Kaldera Masurai yang memperlihatkan dinding kaldera bagian barat yang relatif lebih landai.

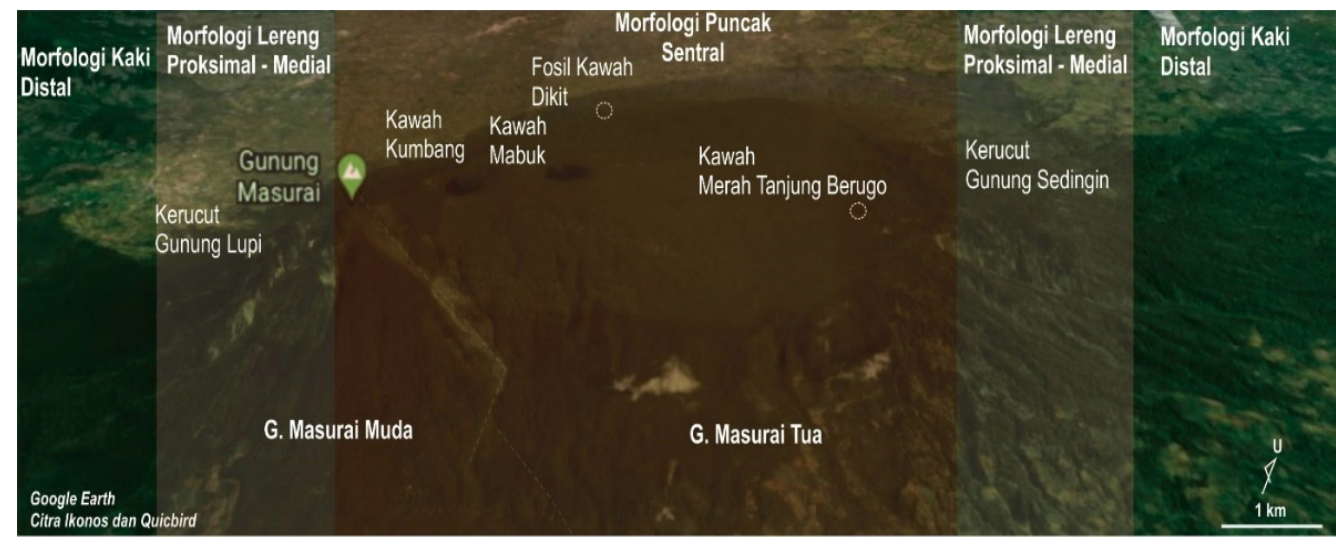

Gambar 4. M orfologi Kaldera Masurai yang memperlihatkan bentang alam dan manifestasi geologi. Keterdapatan manifestasi mengikuti fasies morfologi kaldera.

Keberadaan Kawah Kumbang, Kawah Mabuk, Kawah Merah Tanjung Berugo, dan Kawah Dikit merupakan kawah sisa dari Gunung Masurai Tua, namun untuk Kawah Dikit, kekosongan air diinterpretasikan oleh peranan sesar yang berarah timurlaut baratdaya yang menyebabkan munculnya zona amblesan ataupun debris. Keberadaan kerucut Gunung Dikit merupakan kerucut parasiter yang berdekatan spasial dengan Kawah Dikit diinterpretasikan sebagai satu sistem kerucut dan kawah gunung api yang juga merupakan bagian dari Gunung Masurai Tua. Kerucut Gunung Lupi di bagian barat kaldera diinterpretasikan sebagai kerucut parasiter dari Gunung Masurai Muda. Keberadaan sesar di antara kerucut Gunung Masurai Muda dan
Kawah Kumbang sebagai bagian dari proses struktural setelah pembentukan kaldera (Gambar 7).

Telaga Biru merupakan bagian dari Gunung Masurai Tua, keberadaannya berdekatan dengan jalur sesar berarah baratlaut-tenggara yang berawal dari bagian selatan kaldera. Danau Pauh dan Danau Kecil merupakan bagian dari danau gunung api dari bagian Gunung Masurai Muda, produk piroklastik dan lahar sebagai indikasi bahwa produk ini bagian dari kaki distal kaldera ataupun bagian dari Gunung Masurai Muda. Kedua danau ini diinterpretasi sebagai bagian dari kerucut samping sinder dari erupsi Gunung M asurai M uda. 


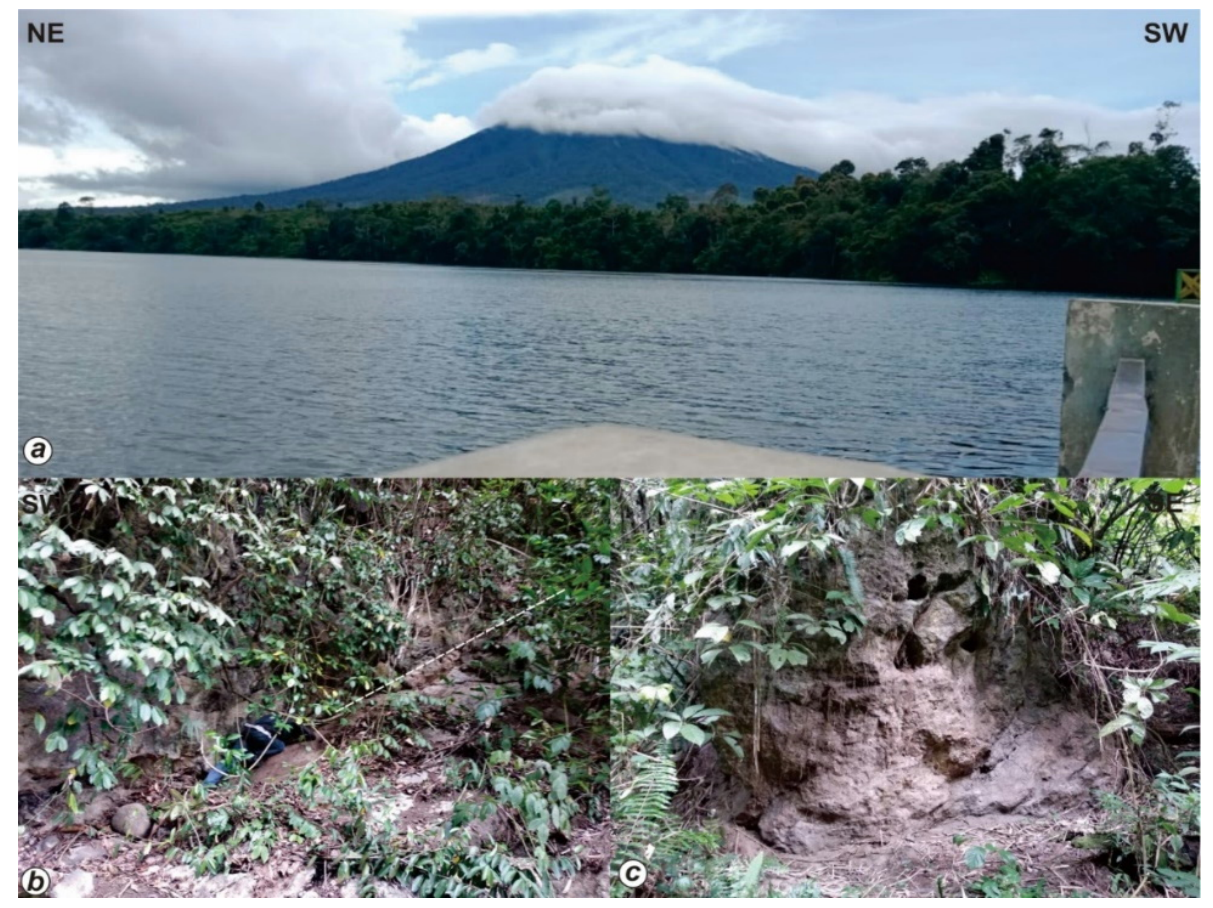

Gambar 5. (a) Bentang alam Kaldera M asurai yang terlihat dari arah badatdaya di sekitar Danau Pauh, (b) Singkapan lava dasit yang merupakan produk dari Gunung Masurai Muda bagian dari Kaldera Masurai, garis putih putus-putus merupakan jalur Sesar M asurai Muda, (c) Singkapan piroklastik dari produk Kaldera M asurai, dengan ketebalan singkapan $\pm 3 \mathrm{~m}$. Titik lokasi dari gambar ini dilihat di Gambar 7.

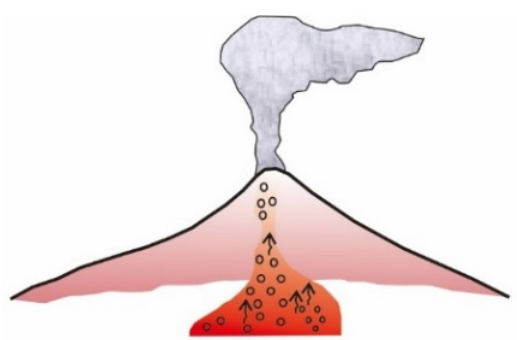

a. Erupsi besar Gunung Api Masurai Tua

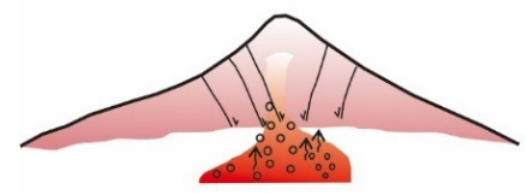

b. Struktural Gunung Api Masurai Tua

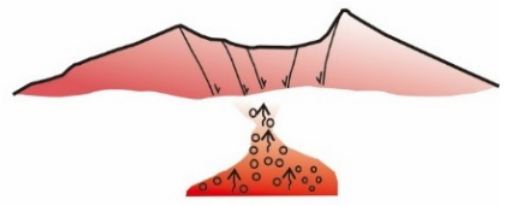

c. Runtuh bagian puncak akibat ruang kosong

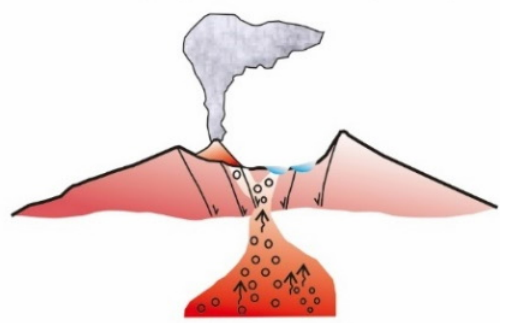

d. Kaldera Masurai dan Gunung Masurai Muda

Gambar 6. Proses pembentukan Kaldera Masurai. (a) Erupsi besar Gunung Api Masurai Tua pada Plistosen Akhir, (b) Terjadinya mekanisme struktural pada morfologi puncak hingga lereng proksimal, (c) Runtuhnya morfologi tersebut yang disebabkan oleh struktural dan ruang kosong pada kantong magma akibat dari erupsi besar, (d) Pembentukan kaldera dan tumbuhnya Gunung Masurai Muda diiringi dengan pembentukan kawah. 


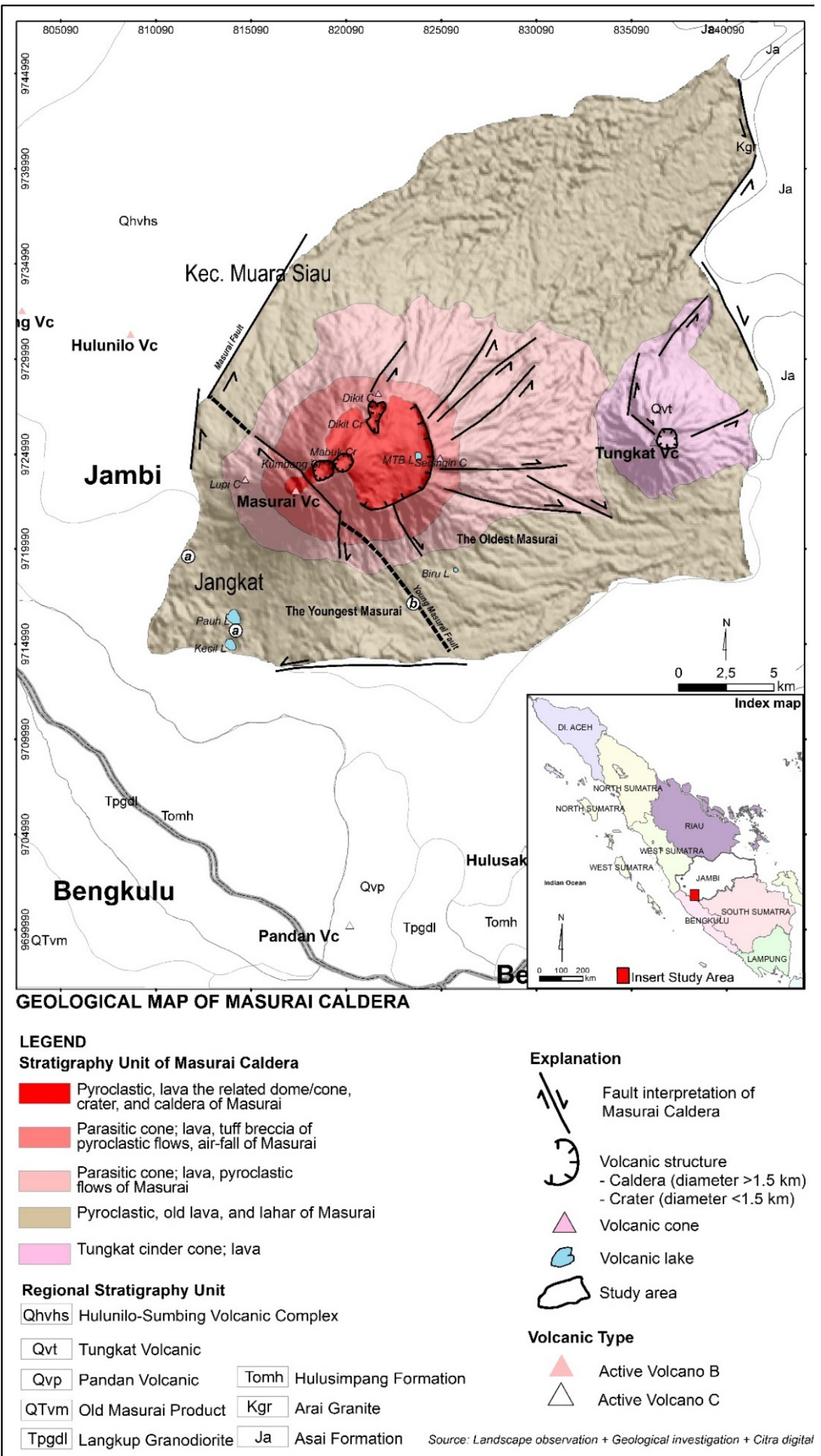

Gambar 7. Peta Geologi Kaldera M asurai. 
Bentang alam dan manifestasi geologi yang ada di morfologi Kaldera Masurai merupakan bagian dari keutuhan proses pembentukan morfologi kaldera. Tatanan geologi pembentukan Kaldera M asurai tentu memiliki keterkaitan terhadap Segmen Dikit yang merupakan bagian dari Sesar Sumatera yang aktif.

Dalam penelitian selanjutnya perlu dilakukan metode analisis penelitian lebih detail, meliputi analisis petrografi batuan, geokimia batuan, dan pentakrihan umur batuan dari Kaldera Masurai. Sehingga nantinya akan didapatkan secara utuh informasi dari pembentukan Kaldera Masurai yang membentuk morfologi fisik kaldera saat ini.

\section{KESIMPULAN}

Berdasarkan hasil analisis dan interpretasi dalam penelitian dari morfologi fisik Kaldera Masurai, didapatkan kesimpulan sebagai berikut:

a. M orfologi fisik Kaldera M asurai terdiri dari morfologi puncak kaldera dengan bentang alam dan manifestasi meliputi cincin kaldera; kawah gunung api meliputi Kawah Kumbang, Kawah Mabuk, Kawah Merah Tanjung Brugo, dan fosil Kawah Dikit; Kerucut Gunung Masurai Muda di bagian barat kaldera.

b. Morfologi lereng proksimal-medial terdiri dari kerucut Gunung Sedingin di bagian tenggara, kerucut Gunung Dikit di bagian utara-timurlaut dari Kaldera M asurai yang merupakan bagian dari kerucut parasiter Gunung M asurai Tua, dan kerucut Gunung Lupi di bagian barat Kaldera yang merupakan bagian dari kerucut parasiter Gunung M asurai M uda. Pada lereng medial juga terdapat manifestasi Danau Telaga Biru yang termasuk ke dalam produk Gunung M asurai Tua.

C. Danau Pauh dan Danau Kecil berada di morfologi kaki ataupun distal dari kaldera yang merupakan bagian dari produk Gunung M asurai M uda.

d. M orfologi fisik Kaldera M asurai terdiri dari morfologi Masurai Tua dan morfologi Masurai Muda yang dibatasi oleh Sesar Masurai Muda.

e. Bentang alam dan manifestasi geologi dari Kaldera Masurai merupakan suatu proses yang utuh dari erupsi besar Gunung Masurai Tua, berlanjut dengan pembentukan kaldera, dan diakhiri dengan tumbuhnya Gunung M asurai Muda yang membentuk morfologi fisik Kaldera Masurai saat ini.

f. Memahami keutuhan morfologi fisik Kaldera Masurai, hubungannya terhadap bentang alam dan manifestasi merupakan salah satu upaya mempelajari dari penemuan kaldera terakhir di Sumatera dan posisinya terhadap kaldera yang lainnya serta keberadaan sumber daya geologi.

\section{UCAPAN TERIMA KASIH}

Penulis mengucapkan terima kasih kepada pihak-pihak terkait yang telah memberi dukungan terhadap penelitian ini, terutama Tim CNJ. Terima kasih untuk Program Studi Teknik Geologi Universitas Jambi.

\section{DAFTAR PUSTAKA}

A dler, J., \& Pratama, T. B. (2018). Identifikasi Pola Warna Citra Google Maps menggunakan Jaringan Syaraf Tiruan Metode Levenberg Marquardt dengan MatLab Versi 7.8. Komputika. Jurnal Sistem Komputer, 7(2), 95101.

East, M ., M uller, R. D., W illiams, S., Zahirovic, S., \& Heine, C. (2020). Subduction History Reveals Cretaceous Slab Superflux as a Possible Cause for the Mid-Cretaceous Plume Pulse and Superswell Events. Gondwana Research, 79, 125-139.

Favallim, M., Karatson, D., M azzuoli, R., Pareschi, M. T., \& Ventura, G. (2005). Volcanic Geomorphology and Tectonics of The Aeolian Archipelago (Southern Italy) Based on 
Integrated DEM Data. Bulletin Volcanology, 68 , 157- 170.

Geshi, N., Ruch, J., \& A cocella, V. (2014). Evaluating Volumes for M agma Chambers and Magma Withdrawn for Caldera Collapse. Erath and Planetary Letters, 396(107-115).

Geshi, N., Yamada, I., M atsumoto, K., Nishihara, A., \& Miyagi, I. (2020). Accumulation of Rhyolite Magma and Triggers for a CalderaForming Eruption of the Aira Caldera, Japan. Bulletin of $\mathrm{V}$ olcanology, 82:44, 1-18.

Gottsmann, J., \& Marti, J. (2008). Caldera Volcanism: Analysis, M odelling And Response. Elsevier, AE Amsterdam, The N etherlands, 492.

Gregg, P. M., Grosfils, E. B., \& de Silva, S. L. (2015). Catastrophic Caldera-Forming Eruptions II: The Subordinate Role of M agma Buoyancy as An Eruption Trigger. Journal of Volcanology and Geothermal Research, 305, 100-113.

Grosse, P., \& Kervyn, M . (2018). M orphometry of Terrestrial Shield Volcanoes. Geomorphology, 304, 1-14.

Gudmundsson, A. (2012). Strengths and Strain Energies of Volcanic Edifices: Implications for Eruptions, Collapse Calderas, and Landslides. Nat. H azards Earth Syst. Sci, 12(7), 2241-2258.

Hall, R. (2014). Indonesian Tectonics: Subduction, Extension, Provenance and M ore. Proceedings, Indonesian Petroleum Association Thirty-Eighth Annual Convention \& Exhibition, IPA 14-G-360.

Hall, R., \& Spakman, W. (2015). M antle Structure and Tectonic History of SE A sia. Tectonophysics, $658,14-45$.

Hall, Robert. (2012). Late Jurassic-Cenozoic reconstructions of the Indonesian region and the Indian Ocean. Tectonophysics, 570-571, 141.

https://doi.org/https://doi.org/10.1016/j.tecto.20 12.04.021

Hall, Robert. (2013). The palaeogeography of Sundaland and W allacea since the Late Jurassic. Journal of Limnology, 72. https://doi.org/10.4081/jlimnol.2013.s2.e1

Hayati, N., \& Taufik, M. (2011). Kajian Ketelitian Planimetris Citra Resolusi Tinggi Pada Google Earth Untuk Pembuatan Peta Dasar Skala 1: 10000 Kecamatan Banjar Timur Kota Banjarmasin. Geoid, 07(01), 052-057.
Hernando, I. R., Petrinovic, I. A., Gutierrez, D. A., Bucher, J., Fuentes, T. G., \& Aragon, E. (2019). The Caldera-Forming Eruption of The Quaternary Payún Matrú Volcano, Andean Back-Arc of The Southern Volcanic Zone. Journal of Volcanology and Geothermal Research, 384, 15- 30.

Hernando, I. R., Petrinovic, I. A., Llambías, E. J., D'Elia, L., González, P. D., \& A ragón, E. (2016). The Role of M agma M ixing and M afic Recharge in The Evolution of a Back-Arc Quaternary Caldera: The Case of Payún Matrú, Western Argentina. Journal of Volcanology and Geothermal Research, 311, 150-169.

Hutchison, C. S. (2014). Tectonic Evolution of Southeast Asia. Bulletin of the Geological Society of M alaysia, Vol. 60, 1-18.

Karlstrom, L., Wright, H. M., \& Bacon, C. R. (2015). The Effect of Pressurized Magma Chamber Growth on Melt M igration and PreCaldera Vent Locations Through Time at M ount M azama, Crater Lake, Oregon. Journal of Volcanology and Geothermal Research, 412, 209-219.

KESDM. (2015). Masurai Kaldera Besar yang Terlewatkan. Badan Geologi Pusat Survei Geologi. https://psg.bgl.esdm.go.id

KESDM. (2021). Daftar Gunung Api di Indonesia. Badan Geologi Pusat Vulkanologi Dan Mitigasi Bencana Geologi. https://pvmbg.bgl.esdm.go.id

M etcalfe, I. (2013). Gondwana dispersion and A sian accretion: Tectonic and palaeogeographic evolution of eastern Tethys. Journal of Asian Earth Sciences, 66, 1-33. https://doi.org/10.1016/j.jseaes.2012.12.020

Metcalfe, I. (2017). Tectonic evolution of Sundaland. Bulletin of the Geological Society of Malaysia, Vol. 63, 27-60.

Natawidjaja, D. H. (2018). Major Bifurcations, Slip Rates, and A Creeping Segment of Sumateran Fault Zone in Tarutung-Sarulla-SipirokPadangsidempuan, Central Sumatera, Indonesia. Global Colloquium on GeoSciences and Engineering 2017; IOP Conf. Series: Earth and Environmental Science, 118, 1-11.

Rachmat, H., Rosana, M. G., W irakusumah, A. J., \& Jabbar, G. A. (2016). Petrogenesis of Rinjani Post-1257-Caldera-Forming-Eruption Lava 
Flows. Indonesian Journal on Geoscience, 107126.

Rudianto, B. (2010). Analisis Ketelitian Objek pada Peta Citra Quickbird RS 0,68 m dan Ikonos RS $1,0 \mathrm{~m}$. Jurnal Rekayasa, LPPM Itenas XIV, 156164.

Suwargana, N. (2013). Resolusi Spasial, Temporal, dan Spektral Pada Citra Satelit Landsat, SPOT dan Ikonos. J. IIm. WIDYA 1, 167-174.

Sweeney, M. R., Grosso, Z. S., \& Valentine, G. A. (2018). Topographic Controls on a Phreatomagmatic Maar-Diatreme Eruption: Field and N umerical Results from The H olocene Dotsero Volcano (Colorado, USA). Bulletin of Volcanology, Vol. 80, 78.

Sweeney, M . R., \& V alentine, G. A. (2017). Impact Zone Dynamics of Dilute Mono and Polydisperse ets and Their Implications for The Initial Conditions of Pyroclastic Density Currents. Physics of Fluids, 29(093304).

Thouret, J. C. (1999). Volcanic Geomorphology an O verview. Earth Science Reviews, 47, 95- 131.

Utama, H. W. (2020). Struktur Geologi dan Vulkanostratigrafi; Analisis Model Elevasi Digital Dan Citra Landsat 8. Jurnal Geofisika Eksplorasi, 6(2), 156-168.

Utama, H. W., Said, Y. M., Siregar, A. D., \& A dhitya, B. (2021). The Role of Sumatera Fault Zone of Dikit Fault Segment to Appearance of Geothermal Features on the Grao Sakti, Jambi, Indonesia. Proceedings of the 3rd Green Development International Conference (GDIC
2020) Atlantis Press; Advances in Engineering Research, 205, 367-375.

Valentine, G. A., \& Cole, M. A. (2021). Explosive Caldera-Forming Eruptions and Debris-Filled Vents: Gargle Dynamics. Geology, 49.

Valentine, G. A., Palladino, D. M., DiemK aye, K., \& Fletcher, C. (2019). Lithic-Rich and Lithic-Poor Ignimbrites and Their Basal Deposits: Sovana and Sorano Formations (Latera Caldera, Italy). Bulletin of $\mathrm{V}$ olcanology, Vol. 81, 29.

Valentine, G. A., \& Sweeney, M. R. (2018). Compressible Flow Phenomena at Inception of Lateral Density Currents Fed by Collapsing GasParticle Mixtures. Journal of Geophysical Research: Solid Earth, 123, 1286-1302.

Van Bemmelen, R. W. (1949). The Geology of Indonesia (2nd ed.). General Geology of Indonesia and Adjacent Archipelagoes.

Yasuda, Y., \& Suzuki-Kamata, K. (2018). The Origin of Coarse Lithic Breccia in the $34 \mathrm{ka}$ Caldera-Forming Sounkyo eruption, Taisetsu Volcano Group, Central Hokkaido, Japan. Journal of Volcanology and Geothermal Research, 357, 287- 305.

Zahirovic, S., Seton, M., \& Muller, R. (2014). The Cretaceous and Cenozoic Tectonic Evolution of Southeast A sia. Solid Earth, 5, 227-235. 